\title{
Village Fund for Peatlands Restoration: Study of Community's Perceived Challenges and Opportunities in Muaro Jambi District
}

\author{
Mahpud Sujai ${ }^{1,}{ }^{,}$, Kosuke Mizuno ${ }^{1}$, Tri Edhi Budhi Soesilo ${ }^{1}$, Riko Wahyudi ${ }^{2,3}$, Joko Tri Haryanto ${ }^{4}$ \\ 1 School of Environmental Science, University of Indonesia, Indonesia \\ 2 Indonesian Expert Association for Climate Change and Forestry (APIKI), Indonesia \\ 3 Natural Resource and Environment Management Agency-Indonesian Ulema Council (LPLH\&SDA-MUI), \\ Indonesia \\ 4 Fiscal Policy Agency, Ministry of Finance, Indonesia \\ * Correspondence author: mahpud.sujai@ui.ac.id, kosuke.mizuno@ui.ac.id
}

\begin{abstract}
Peatlands conversion to dryland for plantation has caused environmental havoc and is more prone to natural disasters in Indonesia. Community engagements under village administration should be the main strategy for supporting peatlands restoration. Since the new law on villages was enacted in 2014, the village has gained authority and delegated responsibilities from the upper-level government to make rural development decisions in various sectors, including those connected to environmental management, such as peatland restoration. The recognition of authority is followed by the transfer of significant funds, called village funds, from the central government as a form of commitment to undertake the village law. Currently, applied regulations allow community engagement to utilize the village fund for supporting peatland restoration. This study investigated the community's perceptions of village fund utilization for peatland restoration through in-depth interviews and questionnaires with site-level stakeholders that influence village budget allocation-related policies. The investigated aspects included village budgeting and development planning mechanism, the capacity of the community, and rules of district government in supervising the villages. Based on our findings, the identified challenges include the absence of environmental aspects as a part of village development pillars for developing village planning and budgeting, lack of community's environmental-economical nexus knowledge, and lack of district government in supervising village fund utilization and management at the site-level. However, the opportunities to direct the village fund utilization for peatlands restoration are widely open by strengthening the roles of district government to improve village fund governance at the site level.
\end{abstract}

Keywords: Peatland; Restoration; Village; Village fund; Community engagement

\section{Introduction}

With the total land area of about 188.2 million hectares, Indonesia is the country with the largest land area in South East Asia. About 40.2 million hectares of that land area are wetlands, and an estimated 20.6 million hectares are peatlands (Wahyunto et al., 2003). Indonesia's peatlands are the fourth largest globally after Canada, Russia, and United States (Mubekti, 2011), and are considered as the largest tropical peatlands in the world which account for $56 \%$ of the world's total tropical peatlands (Badan Restorasi Gambut, 2016). The peatlands are entirely located in the three largest islands in Indonesia: Sumatra island has 6.3 million hectares of peatlands while the Papua and Kalimantan islands each have 7 and 5.1 million hectares of peatlands, respectively (Badan Restorasi Gambut, 2016). Out of the three islands, Sumatra's peatland is the most vulnerable since it suffers from the most extensive land conversion due to the expansion of plantations, especially palm oil mainly by the corporations that hold cultivation rights (Hak Guna Usaha, HGU), and local communities (Mizuno et al., 2016).

Peatland conversion can be a potential source of emissions of carbon dioxide, methane, and nitrous oxide content in terrestrial ecosystems (Wahyunto et al., 2003). Methane is a greenhouse gas that has a potential 21 times greater than carbon dioxide in causing global warming (Liu et al., 2015). Meanwhile, carbon dioxide gas emissions of peatlands stem from the loss of carbon deposits of plant biomass and mainly from carbon stocks in peat soils. Agus et al. (2012) stated that every one meter of peat thickness stores 300-700 tons of carbon/hectare. Jaenicke et al. (2008) estimate 
that the total carbon stored on peatlands in Indonesia is around 55 gigatons which means that the conversion of peat soils can potentially be one of the largest sources of greenhouse gas emissions into the atmosphere produced by Indonesia.

Peatland restoration is a method of land rehabilitation that acts as one of the vital disaster mitigation activities, particularly in peatland areas where degradation can lead to various disasters including forest fires. There are five steps taken to restore the peatlands: mapping peat; determining the types, actors, and timeframe of restoration implementation; rewetting peat; planting peatlands or revegetation; and empowering local communities (Maturana, 2005). Community empowerment is followed by designing an incentive mechanism for the community to preserve and restore the peatlands.

In Indonesia, one of the entry points of community empowerment is performed through the village administration. The village is the lowest government structure that plays an important role in economic, social, and environmental development. Referring to this fact, the government issued village-related policies to strengthen the villages by giving more authorities and responsibilities, including those related to village environmental development. As a consequence of increasing authorities and responsibilities, the national government transferred a significant fund to the village and called as the village fund. The allocations of this fund increased sharply year to year, rising from 1.4 trillion USD in 2015 to 4,1 and 5 trillion USD in 2018 and 2019, respectively (Kementerian Keuangan Republik Indonesia, 2019).

Village fund aims to finance development, including environmental protection for anticipating various disasters and community empowerment in the village. Village Minister Regulation has already opened an opportunity to prioritize the village fund for environmental protection, including peatland restoration to increase village resilience. This regulation also encourages villages to utilize the fund for addressing their problems, including biophysical issues. Villages with a dominant peatland topography are exceptional because they require different and unique handlings than villages compared to typical dryland topography. Therefore, the utilization of village fund will be more beneficial to be directed following the characteristics of the village topography.

This paper will explore the community's perceptions on challenges and opportunities of distributing and utilizing village fund as an effective fiscal instrument for peatland restoration. The locus of research is Muaro Jambi District in Jambi province, one of the districts that receive the biggest village fund in the province and has a relatively large area of peatlands. This paper proceeds as follows. Section two provides a conceptual framework for analyzing challenges and opportunities of designing village fund for peatland restoration. Literature review about the relation between village governance and peatland restoration and how the village fund as a fiscal instrument for peatland restoration are described in section three. The context of village fund in Indonesia outlined in section four before the description of research methodology in section five. In section six, results of analysis are presented and explored. Based on the results, conclusion is made in section seven. Consequently, policy relevance is proposed in section eight related to village fund management, particularly at the site level.

\section{Conceptual Framework}

We developed a conceptual framework as a guideline in designing village fund for peatland restoration and its challenges and opportunities. It is proceeded by analyzing distribution and utilization stages of village fund and viewed at two contexts, district and village levels. At the district level, it proposes district government guidance on how village funds are utilized. In reference to Village Minister Regulation ${ }^{1}$, the authority to do so falls under the district government. At the village level, it proposes improving the quality and integration of village planning and budgeting processes. Village and district efforts would be interlinked to create harmony between the two levels in supporting peatland restoration programs and activities through village fund. Relations between village plans, village budgets, and village fund as a fiscal instrument for supporting peatland restoration can be viewed in Figure 1 below.

\footnotetext{
${ }^{1}$ Minister of Villages No. 22/2016 on Prioritizing Village Fund Utilization.
} 
DISTRIBUTION STAGE

Rules of District Government:

Integrating environmental indicators into distribution and utilization of the village fund

- $\quad$ Directing and supervising the village fund utilization according to its authority in Law on village

\section{UTILIZATION STAGE}

I

I

I

I

I

I

I

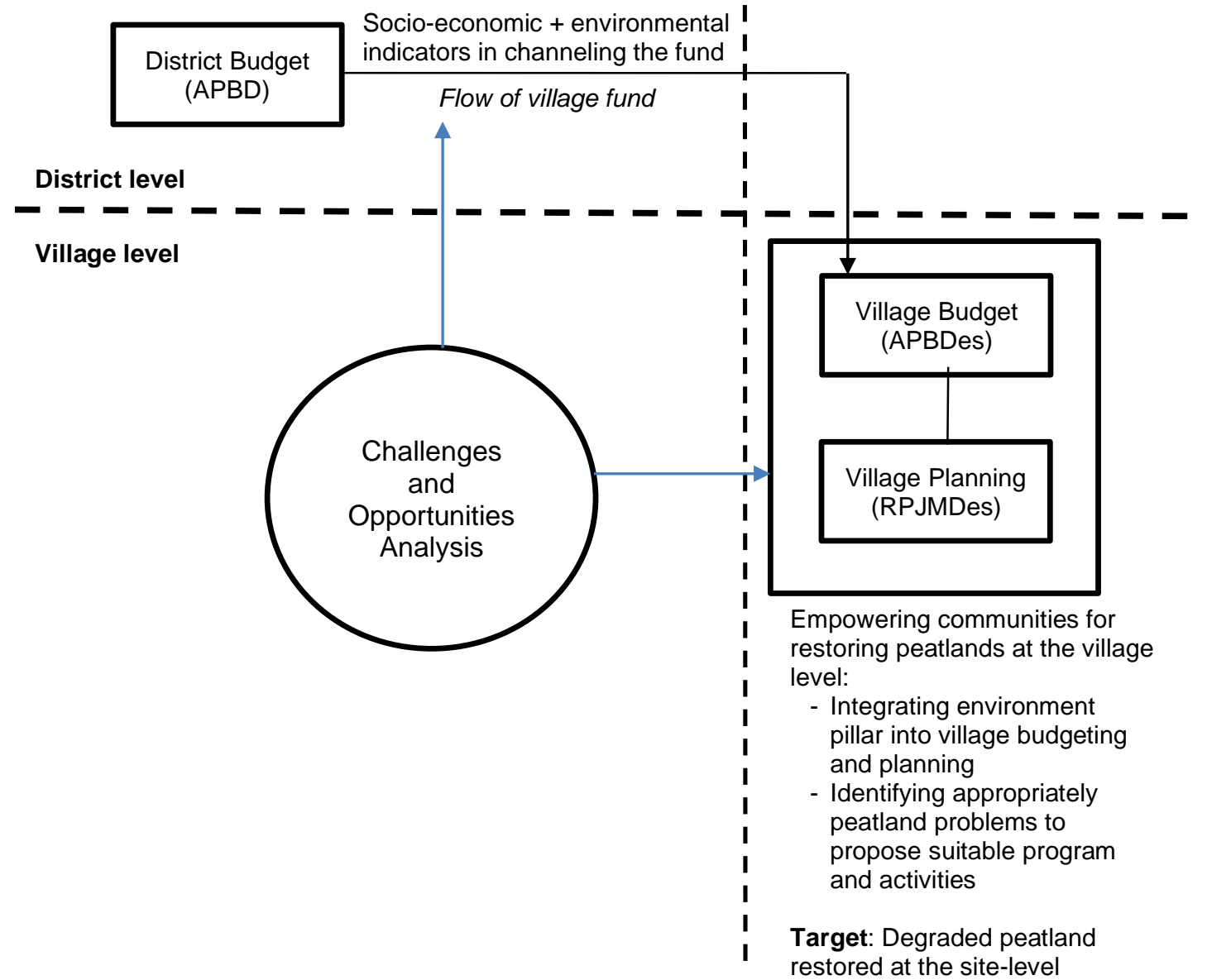

Figure 1. Conceptual framework of village fund utilization and distribution for peatland restoration

For the village planning component, an emphasis would be placed on the integration of the environment protection pillar into the village planning mechanism as an entry point to allocate the fund for peatland restoration. This would be followed by integrating community-based forest management schemes such as village forest, community forest, and others into village planning processes. At present, village-level community forest management is still independent of village planning processes. Capacity building for village officials and facilitators would be necessary to support community-based peatland restoration.

For village budgeting, the mechanism to prioritize and rationalize programs and activities needs to be developed through village deliberation forums (musyawarah rencana pembangunan desa, musrenbangdes). In addition, efforts would be made to establish transparency and accountability mechanisms for village budgets. Meanwhile, the village fund component as the fiscal instrument for peatland restoration would encourage regents to direct the utilization of village funds for peatland restoration and its supporting activities.

\section{Literature Review}

To provide scientific foundations for a conceptual framework, this paper presents literature reviews viewed in the context of as follows. First, village governance, by involving village institutionally as the lowest level jurisdiction to restore peatland. Second, description of village fund 
as an instrument of public finance and how a public finance approach to encourage communitybased peatland restoration.

\subsection{Village governance and peatland restoration}

As the lowest government structure in Indonesia, the village is being given the authority autonomously to manage all of its affairs at its territory (Rudiana \& Afifah, 2019). Bearing in mind the autonomous nature of the village, the village government acts as the main subject of development that has the responsibility to plan and finance programs and activities in the village (Antlöv et al., 2016; Wahyudi, 2017). Considering the important role of the village as an agent of development, the national government has allocated a significant fund for facilitating the role of the village for the development called the village fund (Wahyudi \& Wicaksono, 2020).

Village Minister Regulation concerning the utilization of village funds ${ }^{2}$ explains that the utilization of village fund is prioritized for constructing public infrastructure, improving the quality of village economic growth, and empowering village communities, including environmental protection and management at the village level. Currently, most of the utilization of village fund is directed to the infrastructure and is generally irrelevant to the village's problems and geographic conditions (Wahyudi, 2017). The villages in the coastal areas certainly have different patterns in utilizing the village fund from those in the plateaus. It is also applied in villages in the peatland area that need specific treatments following its characteristics (Rudiana \& Afifah, 2019). In addition, a small portion of the village fund for community empowerment has led to less impact on improving the community's welfare and sustainability of the village environment (Rosyani \& Hariyadi, 2019). It is hoped that the utilization of village fund for community empowerment will be further improved, especially for villages in peatland areas that are vulnerable to the adverse impacts of peat environment degradation. The village governance requires that the utilization of village fund should be deliberated with the community considering socio-economic and environmental aspects and included in village planning and budgeting for the community's welfare, improved livelihood, and sustainable environment of the village (Wahyudi \& Wicaksono, 2020).

The current condition of peatlands in Indonesia is very concerning. Large-scale plantation developments, especially palm oil, have led to severe threats to peatland ecosystems. This condition has caused serious natural disasters, especially forest fires and drought, that almost occur every year. Meanwhile, the communities continue to convert the remaining peatlands into other crops which they deem more profitable (Gunawan et al., 2016). The number of peatlands that are still intact at this time continues to decrease dramatically. Drastic reduction of peatlands is hazardous for environmental sustainability, mainly because of the increased emissions produced. The loss of opportunity costs due to the conversion of natural peatlands into oil palm plantations are estimated to reach between 3.7 to 8.25 USD per ton of $\mathrm{CO}_{2}$ equivalent. This amount is even greater than the carbon price in the market (Gunawan et al., 2012). Peatlands' conservation and restoration are vital to lead the peat into its natural conditions, including biodiversity conservation (Kobayashi, 2016).

Peatland restoration will not succeed without involving the surrounding community through the village governance (Kobayashi, 2016). Increasing the welfare and sustainable livelihoods of the surrounding community is a notable requirement to succeed in peatland restoration. Therefore, the community empowerment program through the village is one of the manners that must be integrated into the peat restoration and preservation-related programs. The village communities need to be empowered and improve their welfare to maintain intact peatlands and return degraded peatlands to better conditions (Gunawan et al., 2016). The village empowerment should be conducted under village administration by integrating and improving village budgeting and planning.

\subsection{Village fund as a fiscal instrument of public finance for peatland restoration}

Public finance is deemed as a potential long-term financial source for environment protection (Streck, 2012) as it is predictable, stable, and reliable (Maguire, 2014) as well as available in sufficient amounts to fund the environment at the subnational level (Nakhooda et al., 2011). Public finance schemes for funding environment protection-related activities such as protected area management

\footnotetext{
${ }^{2}$ Minister of Villages No. 22/2016 on Prioritizing Village Fund Utilization.
} 
and conservation, including peatlands, have been implemented in several countries with multiple schemes (See Kumar \& Managi, 2009; Santos et al., 2012).

In the context of public finance for peatland restoration, an intergovernmental fiscal transfer (IFT) system is being proposed as a possible scheme (Loft et al., 2016; Irawan \& Tacconi, 2016 in the context of REDD+). In the context of Indonesia, one of the possible public finance instruments is the village fund (Wahyudi \& Wicaksono, 2020). This scheme is considered suitable for internalizing positive spillover effects of ecosystem services and biodiversity conservation of forests, including peat forests (Köllner et al., 2000; Loft et al., 2016; Ring, 2008). Modestly, the IFT scheme for environment protection is done by adding ecological considerations into its basic mechanism (Irawan \& Tacconi, 2016), which is illustrated implicitly by Loft et al. (2016) into three aspects, i.e., distribution and utilization. In the distribution aspect, the main point is adding ecological indicators as the basic consideration combined with socio-economic indicators (See Loft et al., 2016). The addition of the indicators tends to encourage the recipient governments to use the funds - an instrument of public finance - to increase the quantity and quality of ecological indicators in the utilization aspect (See Santos et al., 2012).

As the lowest-level jurisdiction in developing countries, including Indonesia, the village is on the front-line, facing negative impacts from environmental havoc (see Pouliot et al., 2012). Considering this, the involvement of villages in protecting the environment, including peatland restoration, is crucial and considered an effective way (Wahyudi \& Wicaksono, 2020). The village governance-related studies argue that decentralization works at the lowest-level jurisdiction much better in environmental protection than top-down mechanisms (Chopra et al., 1990). Villages can play an important role in environmental protection and management through their control mechanisms as they directly interact with their territories (Cronkleton et al., 2011; Danielsen et al., 2011). Therefore, using public finance instruments that target villages for public provision is considered more effective and efficient (Wahyudi \& Wicaksono, 2020).

In the context of Indonesia, the village has the authority to run its role in the local development planning by utilizing its available funds from various sources, mainly from public finance sources (Antlöv et al., 2016). Village fund as one of public finance's instruments is the most significant source of village's finance. In the context of peatland restoration, the village with its mandate and resources can be involved in environmental protection and management programs (Wahyudi, 2017), including peatland restoration, and then designing the monitoring and evaluation mechanisms of those (Danielsen et al., 2011). Village-level planning processes through village development deliberation forums (Antlöv et al., 2016) can be an entry point to integrate peatland conservation and restoration programs into village planning and then financed by the village fund.

The strategic role and outreach of the village, which is in direct contact with the problems at the site level, has made village involvement highly crucial. The involvement of villages by empowering villagers and their financial resources, mainly village fund, will provide a more effective impact in addressing rural problems, especially for peatland restoration (Wahyudi \& Wicaksono, 2020). Therefore, employing village fund as the main source of village finance will be an effective fiscal instrument to support the village empowerment for peatland restoration.

\section{Context: village fund in Indonesia}

Indonesia has a four-layers administrative structure comprising national, provincial, district/municipality, and village. In the context of decentralization in Indonesia, the IFT system must address the fiscal needs of multiple jurisdictions at the sub-national level in executing their roles and responsibilities. Since the Government of Indonesia enacted new regulations about villages in 2014, the villages have received village fund for implementing their mandate. In the presence of village fund, Indonesia's present intergovernmental fiscal transfer (IFT) system comprises of four main instruments: general-purpose funds (DAU), specific-purpose funds (DAK), revenue sharing funds (DBH), and village funds (DD). DAU, DAK, and DBH are transferred to province and district levels, while village fund is allocated to village level via district ${ }^{3}$ (see Figure 2).

\footnotetext{
${ }^{3}$ District supervises villages in using village funds, but, the district cannot utilize the funds and has to directly transfer the funds to villages. Districts can suspend channeling of the funds if villages don't meet
} 


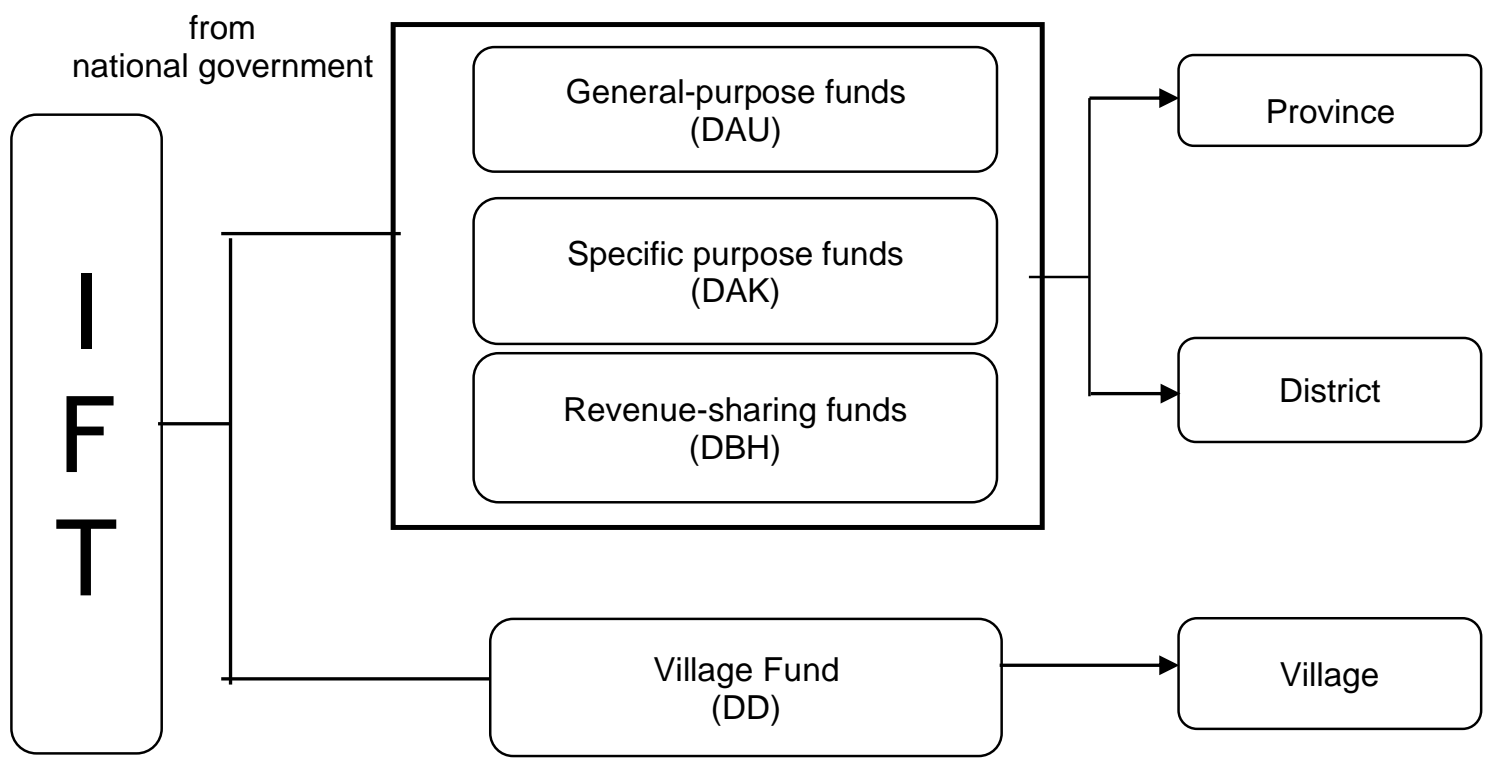

Figure 2. Instruments of Indonesia's IFT system. Source: Modified from Mumbunan (2011)

Each instrument has a different mechanism in distribution and utilization aspects. The village fund has the following mechanisms as a proposed fiscal instrument for peatland restoration in this paper. In the distribution aspect, village funds are allocated to villages via districts in four manners: proportional allocation (77\% of total funds), which means each village will gain the same amount, and formulae-based allocation ( $23 \%$ of total funds). The formulae-based allocation only considers socio-economic indicators i.e.: population size, poverty rate, size of the area, and geographical conditions of villages. In utilization aspect, village fund is being prioritized for village development and empowerment. Environmental protection-related issues, including peatland restoration, are a feature under village empowerment programs. However, detail-derived activities of environmental protection have not been elaborated by the national government.

\section{Methodology}

\subsection{Approach}

The research employs a qualitative approach to explore the village community's perceptions on the distribution and utilization of village fund as one of the fiscal instruments under the IFT system in Indonesia for peatland restoration. The distribution of village fund was analyzed on how the roles of district government in channeling the fund and prioritizing the fund for peatland restoration. The utilization of village fund was analyzed from how the village fund was allocated within village budgeting processes and utilized for peatland restoration at the site level. Challenges and opportunities of distributing and utilizing village fund for peatland restoration were also mapped and analyzed from the community's point of view.

\subsection{Locus of the research}

Muaro Jambi district is chosen as the locus of the research by considering the following two aspects. First, Muaro Jambi district is one of the districts in Jambi province with a vast area of peatlands. The total territory of the district is 544,655 hectares, with peatland areas reaching around $37 \%$ of the total or 200,112 hectares (see Figure 3). Of the total peatland areas, $81 \%(161,695$ hectares) have a thickness of over 3 meters, while the remaining $19 \%(38,417$ hectares) have a thickness of fewer than 3 meters. Considering this in mind, the district has a greater chance of expanding agricultural lands because most of the available peatlands are over 3 meters thick.

requirements as mentioned by Indonesia Regulation. 


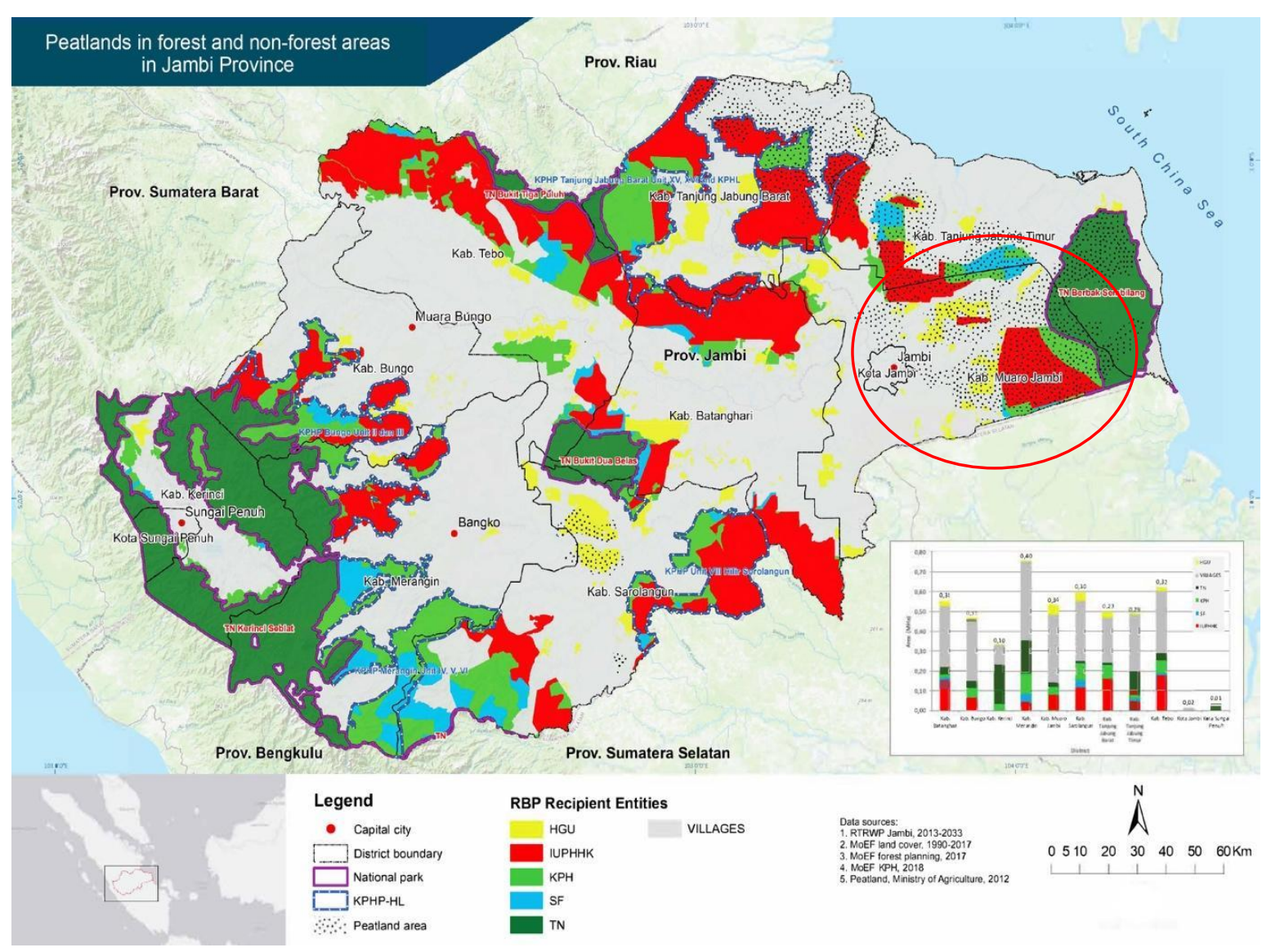

Figure 3. Peatland areas in Jambi Province, including Muaro Jambi District

A simulation to gain a number of villages around peatland areas in Muaro Jambi district was conducted, both inside and within $5 \mathrm{~km}$ from peatlands' outermost boundary. Simulation overlays village administrative boundary map from Badan Pusat Statistik (2019) and forest and peatland area map from Dinas Kehutanan Provinsi Jambi (2020) indicated that there are about 77 villages $(50 \%$ of the total villages) surrounding - inside and adjacent to - peatland areas. If each village received the average village fund to USD 62,000 (Kementerian Keuangan Republik Indonesia, 2020), the total village fund for villages surrounding peatland areas in Jambi province would be around USD 4.8 million (Table 1). This fund has the potential to support peatland restoration by empowering villages.

Table 1. Potential village fund for peatland restoration in Muaro Jambi District

\begin{tabular}{cccc}
\hline $\begin{array}{c}\text { Number of } \\
\text { villages in Muaro } \\
\text { Jambi }\end{array}$ & $\begin{array}{c}\text { Number of the village } \\
\text { inside and within } 5 \\
\mathrm{~km} \text { from peatland } \\
\text { areas }\end{array}$ & $\begin{array}{c}\text { Average village } \\
\text { fund for the } \\
\text { villages in Jambi } \\
\text { (Thousand USD) }\end{array}$ & $\begin{array}{c}\text { Total potential village fund } \\
\text { for peatland restoration } \\
\text { (Thousand USD) }\end{array}$ \\
\hline
\end{tabular}

155

77

62

4,800

Source: Simulation results (2021)

Second, the conversion of peatlands into palm oil plantations has a significant increase in Muaro Jambi District. Suhendri \& Purnomo (2017) stated that the areas of palm oil plantations in the district increased rapidly from 6,000 hectares in 2000 to 160,000 hectares in 2014. Currently, palm oil plantations are the main contributor to the agricultural sector's Gross Regional Domestic Product (GRDP) and a mainstay of income for the communities. The development of the palm oil plantations is changing forest cover, especially on peatlands, in the district, thereby increasing the vulnerability to forest fires and greenhouse gas emissions. Both of these aspects make the district relevant to be selected as a locus of the research. 


\subsection{Data collection}

Collected data consist of primary and secondary data. Primary data was collected through indepth interviews and questionnaires to key persons within villages who were influencing village fund allocation and implementation based on their level of engagement, expertise, experience, network, and credibility. The purposive sampling method was employed to identify the key persons based on the criterion. Meanwhile, secondary data, especially in the form of the distribution and utilization of the village fund, collected from each sample village, namely: villages are defined as the villages concerned with the peat by the Peat Restoration Agency (Badan Restorasi Gambut, BRG). These villages are Sungai Bungur, Sogo, and Seponjen, located in the Kumpeh sub-district, Muaro Jambi District.

The number of interviewees and respondents in each village based on gender are as follows (Table 2).

Table 2. Number of interviewees based on gender in each sample village

\begin{tabular}{lccc}
\hline \multirow{2}{*}{ Village } & \multicolumn{2}{c}{ Number of Interviewees } & \multirow{2}{*}{ Total } \\
\cline { 2 - 3 } & Male & Female & \\
\hline Sungai Bungur & 15 & 10 & 25 \\
Sogo & 7 & 5 & 13 \\
Seponjen & 7 & 5 & 12 \\
\hline Total & $\mathbf{3 0}$ & $\mathbf{2 0}$ & $\mathbf{5 0}$ \\
\hline Percentage & $\mathbf{6 0 \%}$ & $\mathbf{4 0 \%}$ & $\mathbf{1 0 0 \%}$ \\
\hline
\end{tabular}

\subsection{Data Analysis}

This research uses a descriptive exploratory analysis to explain the village community's perceptions of the village fund utilization and distribution for peatland restoration and its challenges and opportunities. As mentioned by Wahyudi \& Wicaksono (2020) that in the context of village fund, the management of the fund covers how the fund is collected, distributed, and utilized. In this research, the analysis is only conducted on the stage of village fund utilization and distribution about how the fund transferred from district to villages and then community plans peatland restorationrelated activities at the site level, allocates the fund for the activities, and then implements the activities. The challenges and opportunities along this process will be examined.

\section{Analysis}

\subsection{Challenges and opportunities in distributing village fund for peatland restoration}

\subsubsection{Distributing village fund from district to villages}

Distribution of village fund from district to village is stipulated through a regent decree. In Muaro Jambi district, the distribution of village fund to villages only follows the mechanism from national to district in two ways: basic allocation ( $77 \%$ of the total fund) and formulae-based allocation (23\% of the total fund). The formulae-based allocation only considers socio-economic aspects: population, poverty rate, size of the area, and geographical conditions (see Figure 4). There is no environmental indicator considered in the process. This condition has not incentivized the villages to utilize their fund for environmental aspects such as peatland restoration. The distribution process of village fund from national to the districts is regulated through a finance minister regulation updated annually.

Although, in the utilization aspect, the village fund can be utilized for the environment and climate change-related activities as regulated through a village minister regulation which is also updated annually. However, because the indicators for distribution of the village fund have not accommodated the environmental aspects, the evaluated targets in utilizing the fund did not consider the peatland restoration aspect for villages within peat areas. The main aspects for evaluating the fund utilizations are poverty alleviation and infrastructure. Therefore, most of the fund are used for those aspects. 


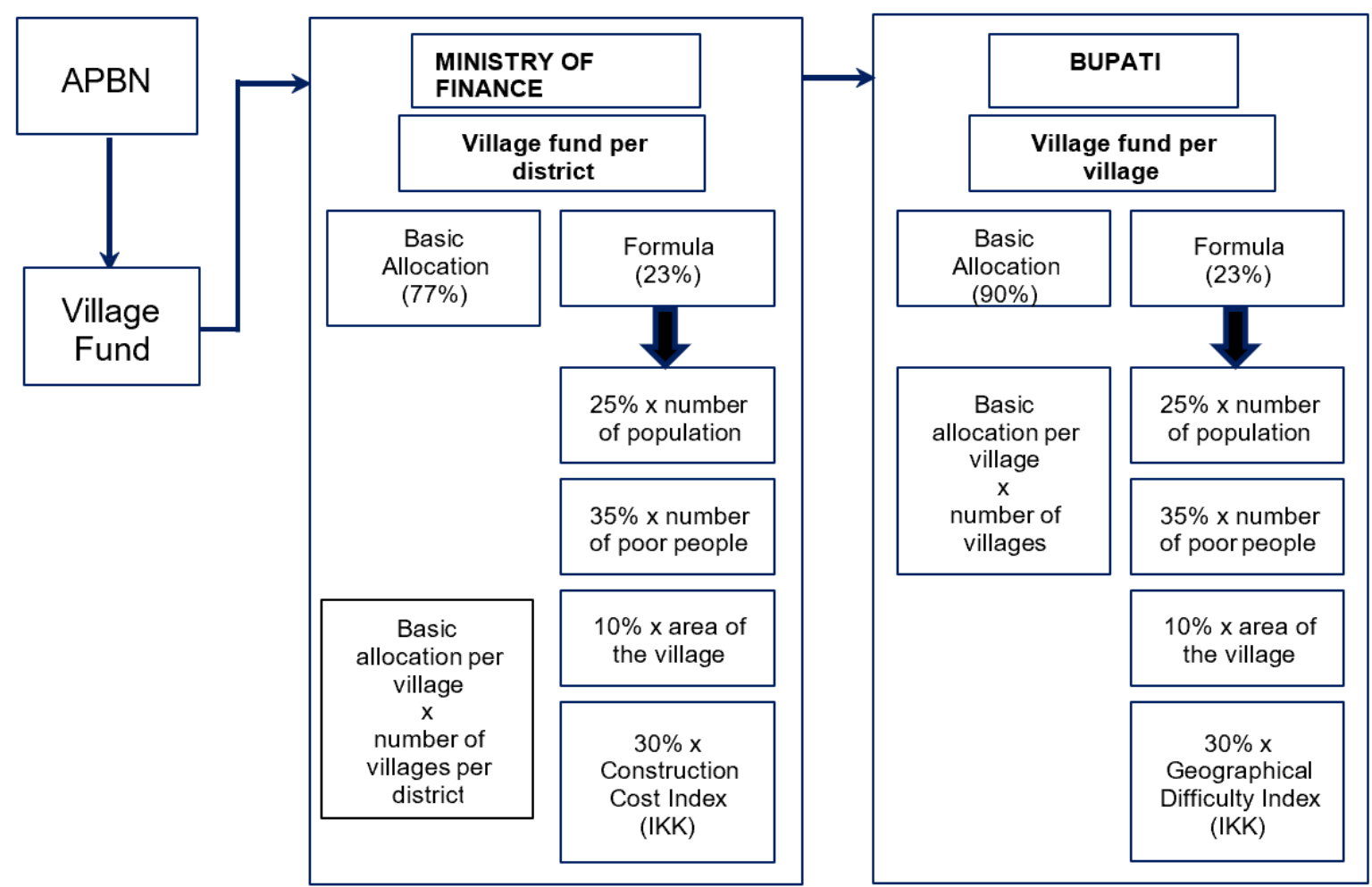

Figure 4. The distribution process of village fund

To incentivize the village community in utilizing the village fund for environmental aspects, including peatland restoration, the environmental indicators should be considered to be integrated into the village fund distribution mechanism. There is an opportunity for the district's authority to refer to village minister regulation in improving the distribution mechanism. The opportunity is to integrate environmental indicators into the existing mechanism as the current indicators only consider social-economic aspects. The existing mechanism has led to the community's perception is that the targets of village fund utilization must refers to the current indicators. Therefore, the integration of environment indicators into the village fund distribution is necessary.

\subsubsection{Directing village fund for peatland restoration}

The current regent decree in distributing and prioritizing village fund has not directed the fund for environmental protection. Furthermore, the priority of village fund has been the discretion of village communities. However, the communities are not supervised and supported with sufficient capacity to manage the fund and develop village plans. We found that almost $90 \%$ of village plans in Muaro Jambi are not relevant to the village problems and potentials, mainly in the environmental aspect. ${ }^{4}$ Based on our interview results, most village plans were tendered to consultant to be developed. The plans have the same template and structure and are suspected to be prepared by the same consultant.

Referring to the finance minister's regulation on village fund distribution, the district governments are given the authority to prioritize the utilization of village fund in their district according to each district's characteristics and needs. The village fund is recorded in the district budget (APBD) and, as a supporting fund for district development, its utilization should be directed by referring to district mid-term development plans (RPJMD). Muaro Jambi district which has $37 \%$ peatland out of its total area and is prone to natural disasters should be managed by engaging the village community using the village fund. The analysis shows, the total village fund from villages around peatland areas is up to USD 4.8 million in 2020, and there is a chance to increase year-toyear. This is an opportunity that village communities also hope for supervision from the district

\footnotetext{
${ }^{4}$ Result of an interview with head of division in Local Development Planning Agency (Bappeda) of Muaro Jambi District.
} 
government.

\subsection{Challenges and opportunities in utilizing village fund for peatland restoration}

\subsubsection{Allocation of village fund for peatland restoration}

Village fund allocation for programs and activities at the village level is conducted through a village development deliberation forum (musrenbangdes). Based on interview results, the pillars of village development are discussed in the musrenbangdes in villages of Muaro Bungo district comprise of village governance, infrastructure, economic development, and human resource development. Communities within the village will be divided into four groups based on the village development pillars. Each group will formulate programs and activities to be proposed in the Village Annual Work Plan (Rencana Kerja Pemerintah Desa, RKPDes) are prepared annually, referring to Village Medium-Term Development Plan (Rencana Pembangunan Jangka Menengah Desa, RPJMDes), which is developed for six years. The RPJMDes was also developed based on the four pillars by considering the village community's proposals.

Table 3. The pillars of village development in preparing medium-term and annual plans at the village level

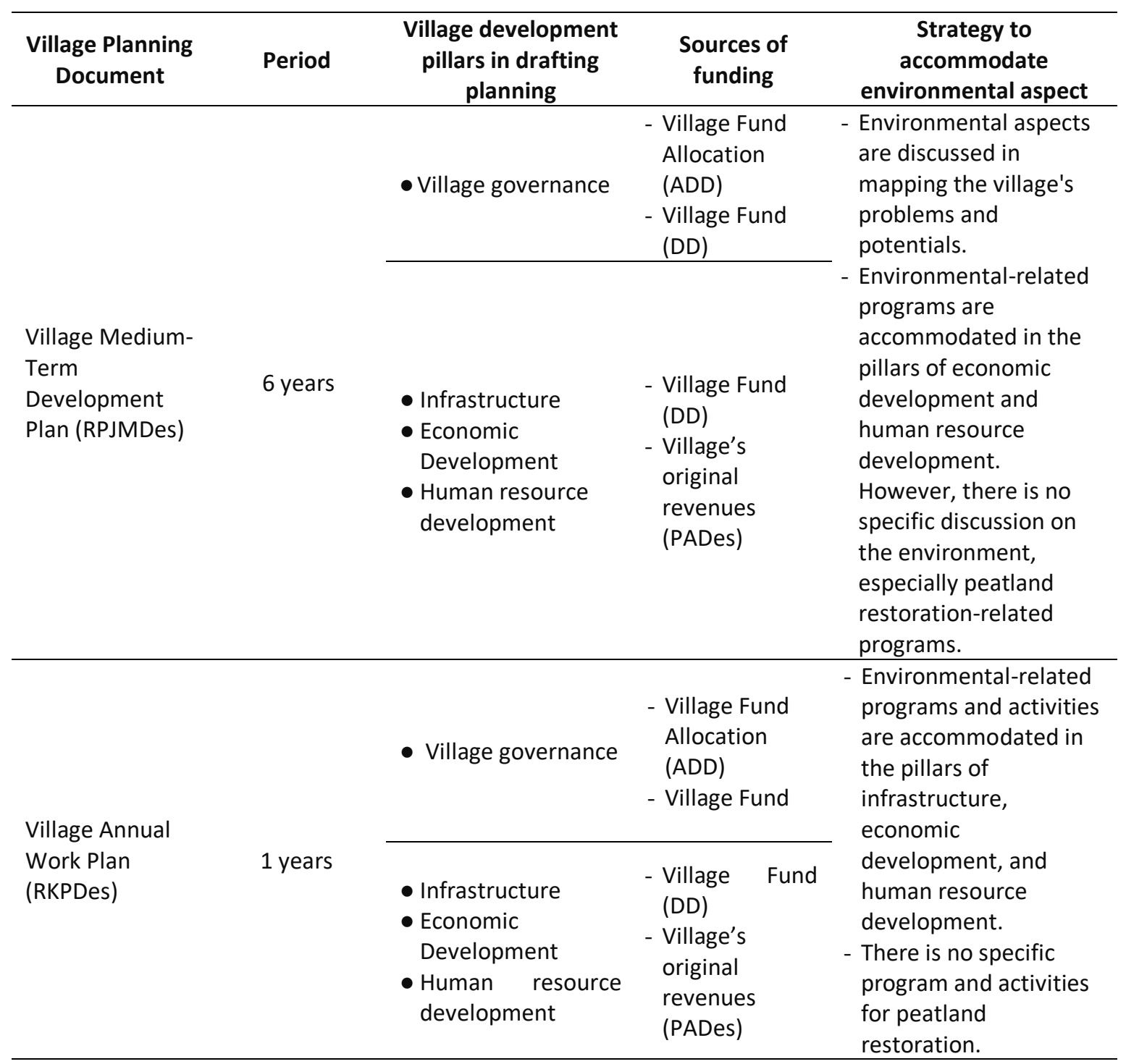

Note: in general, the amount of PADes is minimal compared to other village revenues. The village fund is the largest source of the village's funding. Source: Interview results

However, there is no pillar of village development regarding the environment, specifically discussed in musrenbangdes, both for developing RPJMDes and RKPDes (see Table 3). Meanwhile, RPJMDes and RKPDes are reference documents in utilizing the village fund at the village level and 
poured into village budgeting (Anggaran Pendapatan dan Belanja Desa, APBDes). The first step to ensure that the village fund can be utilized on target, specifically to finance peatland restoration in degraded lands within villages located in peatland areas, is through a village planning process. The absence of an environmental pillar in developing village plans has led to the limitation of proposing environmental-related programs and activities, including peatland restoration in the village areas.

In addition, environmental-related groups within the villages, such as social forestry groups and forest fire care groups (kelompok peduli api) involved in musrenbangdes without representing their groups, however, members of the groups were distributed into four groups of the village development pillars. At a certain level, the groups' plans are not linked to the village planning and budgeting. This condition also leads to efforts to develop peat-friendly community agriculture while improving their skills to be limited. In fact, village minister's regulation on village fund utilization opens a broad opportunity to finance the village environmental aspect, both from infrastructure and community empowerment components.

To open the opportunity of village fund utilization for peatland restoration, integrating environmental pillars into village planning mechanisms is highly required. Determination of development pillars for village planning and budgeting is the authority and discretion of the district government as the supervisor of villages. This is an opportunity to advocate the district government to improve the village planning mechanism by adding an environmental pillar to ensure utilization of the village fund allocated for peatland restoration, especially for villages inside and adjacent to peatlands.

\subsubsection{Implementation of peatland restoration-related programs and activities using the village} fund

The challenges of proposing the peatland restoration-related programs and activities into the village planning, both RPJMDes and RKPDes, have led to the ineffectiveness of utilizing village fund for peatland restoration at the villages located in degraded peatland areas in Muaro Bungo district. The village communities understand that the village fund can be used for peatland restoration and agreed that the fund is utilized to support the peatland restoration-related programs and activities. So far, in the sample villages, the portion of village fund utilization for environmental aspects is still very small compared to the total of the fund (see Table 4). In addition, there is no specific program or activity to restore degraded peatlands, except indirect activities; community empowermentrelated activities, for instance, are accommodated in the pillar of human resource development.

Table 4. The portion of village fund utilization for environmental aspect in the sample villages in 2020

\begin{tabular}{lccc}
\hline Village & $\begin{array}{c}\text { Village fund utilization } \\
\text { for the environment } \\
\text { (thousand USD) }\end{array}$ & $\begin{array}{c}\text { Total of village fund } \\
\text { (Thousand USD) }\end{array}$ & $\begin{array}{c}\text { Percentage of village fund } \\
\text { utilization for environment } \\
\text { (\%) }\end{array}$ \\
\hline Sungai Bungur & 5.7 & 63.6 & 8.9 \\
Sogo & 4.9 & 61.4 & 8.0 \\
Seponjen & 4.6 & 61.4 & 7.5 \\
\hline
\end{tabular}

Note: 1 USD: 14,000 IDR; Environmental-related activities financed by the village fund based on interviewees' perception. Source: Interview results

The villages gain support to restore degraded peatlands through a cooperation with Peat Restoration Agency (Badan Restorasi Gambut, BRG) and international donors. However, the cooperation is not being linked to village planning and budgeting. The activities under the cooperation are also not deliberated within the village planning process at the villages. Therefore, the utilization of village fund for the environment, even the peatland restoration, is very limited in the villages.

As mentioned above, there is no environmental pillar within musrenbangdes to develop village planning, both PBDes and RKPDes, and budgeting (APBDes). This condition has led to a small portion of the village fund for the environment, especially peatland restoration, because of the limitations for proposing peatland restoration-related programs and activities in musrenbangdes into village 
planning documents. Most peatland restoration-related activities are accommodated in human resource development through community empowerment programs such as training, workshops, etc.

Even though environment and conservation have been prioritized in the village fund utilization based on an updated village minister regulation, however, the absence of environmental pillar within musrenbangdes has led to the peatland restoration is not specifically discussed in the forum. Considering the village fund prioritization for the environment, the environmental pillar should be proposed to be integrated into musrenbangdes. The integration of the environmental pillar is expected to increase the utilization of village funds for the environment, specifically for peatland restoration.

\subsubsection{Village community's capacities}

The capacity of village communities has always been the main problem of villages in Indonesia. The limitation of data and information concerning peatland management and adverse impacts of peatland conversion has led to a lack of concern among village communities to propose peatland restoration-related programs and activities. The community also has limited knowledge of how the peatland within their territory should be managed. For the time being, peatland restoration in the sample villages is only supported through a cooperation with Peat Restoration Agency (BRG).

In addition, most of the village facilitators provided through a selection process in the Ministry of Villages, Disadvantaged Regions, and Transmigration also have limited knowledge of and capacity in peatland restoration to facilitate villages in developing their planning and budgeting. This condition also leads to the development of village planning, and budgeting to not be optimal to discuss the village fund for the peatland restoration in musrenbangdes. The facilitators only provided knowledge about the bureaucracy and administrative processes of developing village planning and budgeting; meanwhile, the Ministry of Village has provided a chance to utilize the village fund for capacity building, including the capacity to manage the peatlands, by involving third parties such as academicians from universities, non-governmental organizations (NGOs), consultant companies, etc. This opportunity should be harnessed to increase the community's knowledge of and capacity in peatland management. It will help the village community propose and formulate peatland restoration-related activities to be integrated into village planning and budgeting and then to be implemented.

\section{Conclusion}

In proposing village fund for peatland restoration, it will highly depend on how the fund is distributed and utilized. Referring to the results of the analysis, the absence of environmental indicators in the distribution of village fund from districts to villages, and inadequate supervision of the district government to villages in managing the fund have become challenges in encouraging the utilization of the fund for peatland restoration. In the utilization stage, the absence of environmental pillar in planning and budgeting mechanisms at the village level and lack of village communities' knowledge of and capacity in the peatland management have led the communities to neglect discussions on the utilization of the fund for peatland restoration in musrenbangdes. The communities will only follow existing mechanisms provided by the district government and are still concerned with the lack of legal certainty to directly use village fund for peatland management.

The district government with its authority however, should have an opportunity to integrate the environmental indicators into the existing mechanism of the village fund through close coordination with relevant ministries at the national level such as Ministry of Finance, Ministry of Village, and Ministry of Home Affairs. District government can also direct and prioritize the utilization of village fund according to the district's characteristics, in this context is to have peatland in their territories. At the village level, the communities have the willingness to utilize village fund for peatland restoration. These opportunities need to be supported through a district's policy to include an environmental pillar into musrenbangdes processes for developing village planning and budgeting. To optimize the utilization of the fund for peatland restoration, capacity building for the communities and village facilitators will be required. If the opportunities at the distribution and utilization of the village fund can be appropriately managed, it will encourage the potentials of the 
village fund for peatland restoration.

\section{Policy Relevance}

\subsection{Integrating environmental indicators in distributing village fund from district to villages}

The proposal for integrating environmental indicators into existing mechanisms of village fund distribution will require a close coordination between the Ministry of Finance mandated to regulate the village fund distribution mechanism, and the Ministry of Village mandated to stipulate the village fund utilization. The approvals from these ministries are highly required to provide legal certainty for the district government for including the indicators. The integration is also expected to link the distribution and utilization of village fund, both in implementation and evaluation. The evaluated aspects in the utilization stage should refer to indicators of distribution mechanism.

\subsection{Integrating an environmental pillar into village planning and budgeting processes}

As proposed, to ensure that village environment-related programs and activities are intensively and comprehensively deliberated in musrenbangdes, the environmental pillar should be integrated into the guideline of musrenbangdes provided by the Local Development and Planning Agency (Badan Perencanaan Pembangunan Daerah, Bappeda) at the district level. As villages are under the supervision of the district, the village communities will follow the guidelines provided by the district government in developing village planning and budgeting. After integrating the environmental pillar, the guideline should be framed through a regent decree (peraturan bupati) to enforce the communities to specifically discuss environmental aspects in their village. In addition, the guideline should also provide the environmental pillar of village development concerning how the communities formulate and propose environmental-related activities based on the village's characteristics and typology. Therefore, the villages in the peatland areas will develop peatland restoration and conservation-related programs and activities within the pillar of the environment.

\subsection{Capacity building based on village's environmental characteristics and typology}

A village's environmental characteristics and typology will determine the environmental problems being faced by the community. Villages located in peatland areas - in the lowland typology - will face issues according to peat's characteristics, such as quick-dry and flammable. The village's communities must know the characteristics and understanding of how the peatland areas should be managed and harnessed. Therefore, they will be able to develop programs and activities in addressing the peatland, mainly degraded peatland to be restored, into village planning to be financed by village fund through APBDes.

Considering this in mind, the district government, with its authority, can develop a guideline through a regent decree (peraturan bupati) on the utilization of village fund as a derivative regulation of village minister regulation (permendes). Referring to village fund-related regulations, the district government can prioritize more specifically the utilization of village fund based on the programs and activities prioritized by the Ministry of Village. In this case, the district government is allowed to direct the utilization of village fund for capacity-building programs relevant to the community's needs, especially in the environmental aspect. Based on the regent decree, the communities in peat areas can develop capacity-building programs concerning peatland management, conservation, and restoration. In addition, the district government also has the authority to formulate one of the village authorities, namely: village-scale authority (kewenangan skala desa). In this authority, the district government can determine one of the components within its authority: to protect the environment based on its characteristics and typology and encourage the village communities to increase their capacity related to those aspects. The components of the authority are then stipulated through a regent decree (peraturan bupati).

Author contributions: Designing the study, providing a conceptual framework, data analysis: Author 1; revising data analysis, formulating the results: Author 2; revising the writing, improving the conceptual framework and policy recommendations: Author 3; data collection, data analysis, providing the results: Author 4; revising results and policy recommendation: Author 5 . 
Conflict of interest: The authors declare that they have no competing interests.

Acknowledgment: The authors gratefully acknowledge the support of the University of Indonesia (UI) for funding this research through the International Publication (PUTI) Grant scheme with the contract number of NKB-751/UN2.RST/PPM.00.03.01/2021. We also wish to thank Paul Jeffery and Christian Dunn as well as the editors of this journal and two anonymous reviewers for their insightful comments on earlier drafts of this article.

\section{References}

Agus, F., Subiksa, I.G.M., and Wahyunto. (2012). Pengelolaan Lahan Gambut. In Janudianto (ed), Membangun Kembali Aceh: Belajar dari Hasil Penelitian dan Program Rehabilitasi Aceh Pasca Tsunami (pp. 37-58). World Agroforestry Center.

Antlöv, H., Wetterberg, A., \& Dharmawan, L. (2016). Village governance, community life, and the 2014 village law in Indonesia. Bulletin of Indonesian Economic Studies, 52(2), 161-183. https://doi.org/10.1080/00074918.2015.1129047

Astiani, D., Burhanuddin, B., Curran, L. M., Mujiman, M., \& Salim, R. (2017). Effects of drainage ditches on water table level, soil conditions and tree growth of degraded peatland forests in West Kalimantan. Indonesian Journal of Forestry Research, 4(1), 15-25. https://doi.org/10.20886/ijfr.2017.4.1.15-25

Badan Pusat Statistik [Central Bureau of Statistics]. (2019). Peta Desa di Indonesia. Badan Pusat Statistik (BPS).

Badan Restorasi Gambut [Peat Restoration Agency]. (2016). Rencana Strategis Restorasi Gambut 2016-2020. Badan Restorasi Gambut (BRGM).

Chopra, K., Kadekodi, G.K., Murty, M.N. (1990). Participatory Development: People and Common Property Resources. SAGE Publications.

Cronkleton, P., Bray, D. B., \& Medina, G. (2011). Community forest management and the emergence of multi-scale governance institutions: Lessons for REDD+ development from Mexico, Brazil and Bolivia. Forests, 2(2), 451-473. https://doi.org/10.3390/f2020451

Danielsen, F., Skutsch, M., Burgess, N. D., Jensen, P. M., Andrianandrasana, H., Karky, B., ... \& Zahabu, E. (2011). At the heart of REDD+: a role for local people in monitoring forests?. Conservation Letters, 4(2), 158-167. https://doi.org/10.1111/j.1755263X.2010.00159.x

Dinas Kehutanan Provinsi Jambi [Jambi Province Forestry Office]. (2020). Peta Kesatuan Pengelolaan Hutan (KPH) dan Gambut di Provinsi Jambi. Dinas Kehutanan Provinsi Jambi.

Gunawan H., Kobayashi S., Mizuno K., Kono Y., Kozan O. (2016) Sustainable Management Model for Peatland Ecosystems in the Riau, Sumatra. In Osaki M., Tsuji N. (eds.), Tropical Peatland Ecosystems (pp. 113-123). Springer. https://doi.org/10.1007/978-4-431-55681-7_7

Gunawan, H., Kobayashi, S., Mizuno, K., \& Kono, Y. (2012). Peat swamp forest types and their regeneration in Giam Siak Kecil-Bukit Batu Biosphere Reserve, Riau, East Sumatra, Indonesia. Mires and Peat, 10(5), 1-17.

Irawan, S., \& Tacconi, L. (2016). Intergovernmental Fiscal Transfers, Forest Conservation and Climate Change. Edward Elgar Publishing.

Jaenicke, J., Rieley, J. O., Mott, C., Kimman, P., \& Siegert, F. (2008). Determination of the amount of carbon stored in Indonesian peatlands. Geoderma, 147(3-4), 151-158. https://doi.org/10.1016/j.geoderma.2008.08.008

Kementerian Keuangan Republik Indonesia [Ministry of Finance, Republic of Indonesia]. (2019). Laporan Realisasi Anggaran Dana Desa di Indonesia. Ministry of Finance.

Kementerian Keuangan Republik Indonesia [Ministry of Finance, Republic of Indonesia]. (2020). Perkiraan Anggaran Dana Desa di Indonesia 2020. Ministry of Finance.

Kobayashi, S. (2016). Peatland and Peatland Forest in Brunei Darussalam. In Osaki M., Tsuji N. (eds.), Tropical Peatland Ecosystems (pp. 75-89). Springer. https://doi.org/10.1007/978-4-43155681-7_5

Köllner, T., Schelske, O., \& Seidl, I. (2002). Integrating biodiversity into intergovernmental fiscal 
transfers based on cantonal benchmarking: a Swiss case study. Basic and Applied Ecology, 3(4), 381-391. https://doi.org/10.1078/1439-1791-00104

Kumar, S., \& Managi, S. (2009). Compensation for environmental services and intergovernmental fiscal transfers: the case of India. Ecological Economics, 68(12), 3052-3059. https://doi.org/10.1016/j.ecolecon.2009.07.009

Liu, J., Mooney, H., Hull, V., Davis, S. J., Gaskell, J., Hertel, T., ... \& Li, S. (2015). Systems integration for global sustainability. Science, 347(6225). https://doi.org/10.1126/science.1258832

Loft, L., Gebara, M.F., and Wong, G.Y. (2016). The experience of ecological fiscal transfers. Occasional Paper 154. CIFOR.

Maguire, R. (2014). Public Finance for REDD+ in Kenya. Research Report. Queensland University of Technology.

Maturana, J. 2005. Biaya dan manfaat ekonomi dari pengalokasian lahan hutan untuk pengembangan hutan tanaman industri di Indonesia. Working Paper No. 30(i). CIFOR.

Mizuno, K., Fujita, M., Kawai, S. (2016). Catastrophe and Regeneration in Indonesia's Peatlands: Ecology, Economy, and Society. National University of Singapore Press.

Mubekti, M. (2011). Studi Pewilayahan Dalam Rangka Pengelolaan Lahan Gambut Berkelanjutan Di Provinsi Riau. Jurnal Sains dan Teknologi Indonesia, 13(2), 88-94. https://doi.org/10.29122/jsti.v13i2.883

Nakhooda, S., Caravani, A., Wenzel, A., and Schalatek, L. (2011). The evolving global climate finance architecture. Brief 2 Overseas Development Institute and Heinrich Böll Stiftung North America.

Pouliot, M., Treue, T., Obiri, B. D., \& Ouedraogo, B. (2012). Deforestation and the limited contribution of forests to rural livelihoods in West Africa: evidence from Burkina Faso and Ghana. Ambio, 41(7), 738-750. https://doi.org/10.1007/s13280-012-0292-3

Ring, I. (2008). Integrating local ecological services into intergovernmental fiscal transfers: the case of the ecological ICMS in Brazil. Land Use Policy, 25(4), 485-497. https://doi.org/10.1016/j.landusepol.2007.11.001

Rosyani and Hariyadi, B. (2019). Partisipasi masyarakat dalam pencegahan dan pengendalian kebakaran lahan gambut di Hutan Lindung Gambut Londerang Provinsi Jambi. Jurnal Pembangunan Berkelanjutan, 2(1), 16-39. https://doi.org/10.22437/jpb.v2i1.6435

Rudiana and Afifah, D. (2019). Uniformity of development patterns as a portrait of autonomy of village government in managing village funds. Jurnal Ilmu Pemerintahan Widya Praja, 45(1), 85-98. https://doi.org/10.33701/jipwp.v45i1.340

Santos, R., Ring, I., Antunes, P., \& Clemente, P. (2012). Fiscal transfers for biodiversity conservation: the Portuguese Local Finances Law. Land Use Policy, 29(2), 261-273. https://doi.org/10.1016/j.landusepol.2011.06.001

Streck, C. (2012). Financing REDD+: matching needs and ends. Current Opinion in Environmental Sustainability, 4(6), 628-637. https://doi.org/10.1016/j.cosust.2012.10.001

Suhendri, S., \& Purnomo, E. P. (2017). Penguatan Kelembagaan Dalam Pencegahan dan Pengendalian Kebakaran Hutan dan Lahan di Kabupaten Muaro Jambi Provinsi Jambi. Journal of Governance and Public Policy, 4(1), 174-204. https://doi.org/10.18196/jgpp.v4i1.2645

Wahyudi, R. (2017). An assessment of village funds: Creating fiscal incentive mechanism in Aceh Province. Research Report. Deutsche Gesellschaft für Internationale Zusammenarbeit (GIZ)SICCR TAC.

Wahyudi, R., \& Wicaksono, R. L. (2020). Policy forum: Village fund for REDD+ in Indonesia: Lessons learned from policy making process at subnational level. Forest Policy and Economics, 119, 102274. https://doi.org/10.1016/j.forpol.2020.102274

Wahyunto, S., Ritung, S., and Subagjo, H. (2003). Sebaran Gambut dan Kandungan Karbon di Sumatera dan Kalimantan. Wetlands International-Indonesia Programme \& Wildlife Habitat. 